\title{
Crystal Structure and Catalytic Properties of $\left(\mathrm{C}_{6} \mathrm{H}_{8} \mathrm{~N}\right)_{3}\left[\mathrm{PMo}_{12} \mathrm{O}_{40}\right]$
}

\author{
Tie-Jun Cai, Shu-Zi Lü, Chuan-Lei Zhang, Yi-lan Huang, Ren-yuan Liu, and Qian Deng \\ College of Chemistry and Chemical Engineering, Hunan University of Science and Technology, \\ Xiangtan 411201, P. R. China \\ Reprint requests to Prof. Tie-Jun Cai. Fax: +86-731-58291379. E-mail: tjcai53@163.com
}

Z. Naturforsch. 2011, 66b, 1231 -1236; received October 14. 2011

The 4-picolinium salt $\left(\mathrm{C}_{6} \mathrm{H}_{8} \mathrm{~N}\right)_{3}\left[\mathrm{PMo}_{12} \mathrm{O}_{40}\right]$ was synthesized hydrothermally and characterized by IR spectroscopy, TG-DTA data and single-crystal X-ray diffraction. The results indicate that the compound consists of a $\left[\mathrm{PMo}_{12} \mathrm{O}_{40}\right]^{3-}$ heteropolyoxoanion and 4-picolinium cations $\left[\mathrm{C}_{6} \mathrm{H}_{8} \mathrm{~N}\right]^{+}$. A supramolecular structure is formed via intermolecular hydrogen-bonding between the different structural units. Crystal data: monoclinic, space group $P 2_{1} / c, a=19.7004(3), b=14.0785(2), c=$ 33.0209(5) $\AA, \beta=91.3590(10)^{\circ}, V=9155.8(2) \AA^{3}, Z=8, w R 2=0.0730 .\left(\mathrm{C}_{6} \mathrm{H}_{8} \mathrm{~N}\right)_{3}\left[\mathrm{PMo}_{12} \mathrm{O}_{40}\right]$ has a high catalytic activity for the oxidative elimination of acetone from gases as tested in a continuousflow fixed-bed micro-reactor. When the initial concentration is $5.2 \mathrm{~g} \mathrm{~m}^{-3}$ in air, and the flow rate is $3.3 \mathrm{~mL} \mathrm{~min}^{-1}, 93 \%$ of the acetone is eliminated at $70{ }^{\circ} \mathrm{C}$.

Key words: Heteropolyoxoanion, 4-Picoline, Hydrothermal Method, Crystal Structure, Oxidative Elimination

\section{Introduction}

In the past decades, polyoxometalates (POMs), a unique class of inorganic metal oxide clusters, have attracted great interest not only because of their controllable shape and size, highly negative charges and oxoenriched surfaces, but also due to their potential applications in catalysis, electrical conductivity, gas storage, ion exchange, and biological chemistry [1-4].

Based on POMs, more and more inorganicorganic compounds have been reported in order to combine different inorganic and organic components with unexpected structures and properties: Cao reported two compounds based on Anderson-type polyoxoanions, $\left[\mathrm{Cu}_{2}\left(2,2^{\prime} \text {-bipy }\right)_{2}(\mu\right.$-oxalato $)]\left[\mathrm{Al}(\mathrm{OH})_{7} \mathrm{Mo}_{6} \mathrm{O}_{17}\right]$ and $\left[\mathrm{Cu}_{2}\left(2,2^{\prime} \text {-bipy }\right)_{2}(\mu\right.$-oxalato $)]\left[\mathrm{Cr}(\mathrm{OH})_{7} \mathrm{Mo}_{6} \mathrm{O}_{17}\right] \quad\left(2,2^{\prime}\right.$-bipy $=2,2^{\prime}$-bipyridine $)$ in 2007 [5]. A polyoxometalate-based composite $\left[\mathrm{Ni}(\text { phen })_{2}\right][\mathrm{Hphen}]\left[\mathrm{AsW}_{12} \mathrm{O}_{40}\right]$ (phen $=1,10$ phenanthroline) was hydrothermally synthesized by Wang [6]. The complex [ $\{\mathrm{Na}$ (dibenzo-18-crown-6)$\left.(\mathrm{MeCN})\}_{3}\left\{\mathrm{PMo}_{12} \mathrm{O}_{40}\right\}\right]$ has been reported by You in 2001 [7], which has an unusual structure in which the polyoxoanion is coordinated to three $[\mathrm{Na}$ (dibenzo18-crown-6)(MeCN)$]^{+}$ions through the three terminal oxygen atoms in a single $\mathrm{Mo}_{3} \mathrm{O}_{10}$ triplet. Two new hybrid polyoxo-tungstates, $\left[\operatorname{Co}\left(2,2^{\prime} \text {-bipy }\right)_{3}\right]-$
$\left[\alpha-\mathrm{H}_{5} \mathrm{PW}_{11} \mathrm{CoO}_{40}\right] \cdot 3 \mathrm{H}_{2} \mathrm{O}$ and $\left[\mathrm{Fe}\left(2,2^{\prime} \text {-bipy }\right)_{3}\right]_{2}[\alpha-$ $\left.\mathrm{HBW}_{12} \mathrm{O}_{40}\right] \cdot 2.5 \mathrm{H}_{2} \mathrm{O}$, were published in 2009 [8]. The first example of a two-dimensional structure in $\left(4,4^{\prime}\right.$-bipy $\left.\mathrm{H}_{2}\right)\left[\mathrm{Cu}\left(4,4^{\prime} \text {-bipy }\right)\right]_{2}\left[\mathrm{HPCuMo}_{11} \mathrm{O}_{39}\right]\left(4,4^{\prime}-\right.$ bipy $=4,4^{\prime}$-bipyridine) formed from a polyoxomolybdate chain through the linkage of a transition metal coordination polymer chain was synthesized by $\mathrm{Lu}$ [9]. The compound ( $\mathrm{H}-\mathrm{IDP})_{4}\left[\mathrm{PMo}_{12} \mathrm{O}_{40}\right] \cdot 8 \mathrm{H}_{2} \mathrm{O}$ (IDP $=4$ (imidazole-1-yl)phenol) based on Keggin-type phosphomolybdate has been synthesized, and the report shows that the compound has fluorescence properties [10]. A hybrid $\left(n-\mathrm{Bu}_{4} \mathrm{~N}\right)_{2}\left[\mathrm{Mo}_{6} \mathrm{O}_{17}(\equiv \mathrm{NAr})_{2}\right](\mathrm{Ar}=$ $\left.o-\mathrm{CH}_{3} \mathrm{OC}_{6} \mathrm{H}_{4}\right)$ has also been prepared. In this compound the cluster anions are aggregated into an interesting double chain along the $a$ axis through $\pi-\pi$ stacking and $\mathrm{C}-\mathrm{H} \cdots \mathrm{O}$ hydrogen-bonding interactions. It has also been reported that this solid has a small optical band gap of $2.25 \mathrm{eV}$ [11]. Photosensitivity to ultraviolet light was assessed for the compound $\left[\left(\mathrm{CH}_{3}\right)_{3}\right.$ $\left.\mathrm{CNH}_{3}\right]_{3}\left[\mathrm{PMo}_{12} \mathrm{O}_{40}\right] \cdot 2 \mathrm{H}_{2} \mathrm{O}$. It showed charge-transfer resulting from the oxidation of organic substrates and reduction of the heteropolyanion. The compound immediately induces intense photochromism in the solid state under irradiation by UV light [12].

Compounds based on picoline and polyoxomolybdate and their application in oxidative elimination of organic pollutants in the gas phase have rarely been 


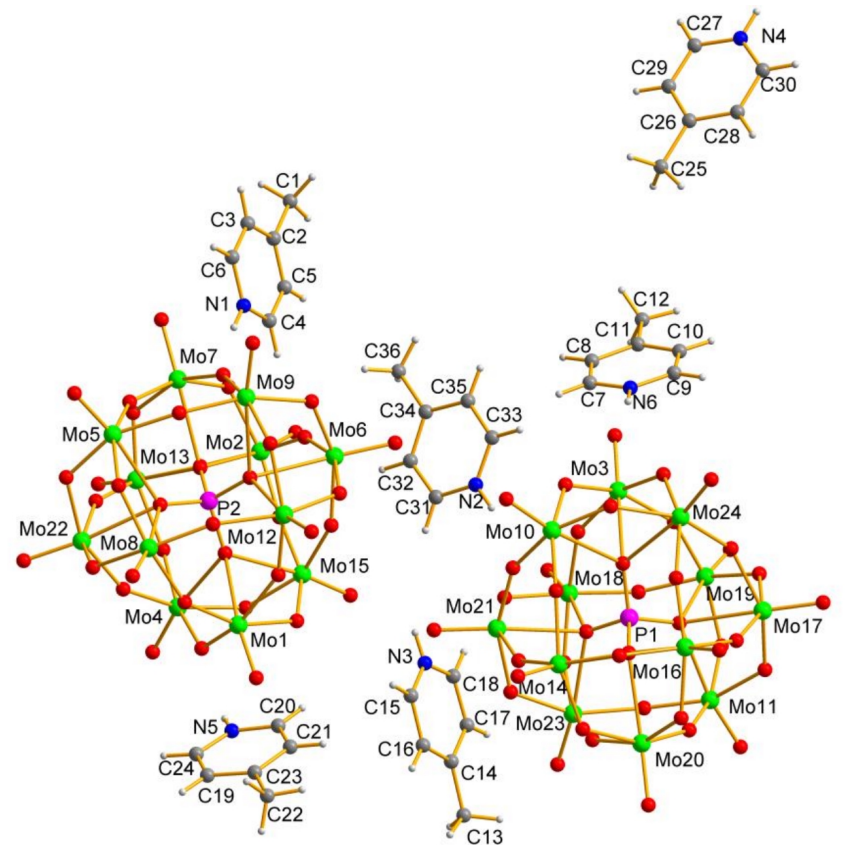

Fig. 1 (color online). View of the molecular components in the crystal structure of $\left(\mathrm{C}_{6} \mathrm{H}_{8} \mathrm{~N}\right)_{3}$ $\left[\mathrm{PMo}_{12} \mathrm{O}_{40}\right]$. reported. Acetone is a typical small molecule organic pollutant. The Chinese Industrial Standard TJ36-79 states that the maximum allowable concentration of acetone is $0.4 \mathrm{~g} \mathrm{~m}^{-3}$ in a workshop atmosphere. Thus the elimination of acetone is significant in environmental protection.

In this paper, the 4-picolinium phosphomolybdate $\left(\mathrm{C}_{6} \mathrm{H}_{8} \mathrm{~N}\right)_{3}\left[\mathrm{PMo}_{12} \mathrm{O}_{40}\right]$ was synthesized by a hydrothermal method, and the oxidative elimination of acetone from air was used as the probe reaction in order to evaluate the catalytic performance of the compound.

\section{Results and Discussion}

\section{Crystal structure description}

The title compound crystallizes in the monoclinic space group: $P 2_{1} / c$ with $Z=8$ (Table 1 ). It consists of two crystallographically independent Keggin anions $\left[\mathrm{PMo}_{12} \mathrm{O}_{40}\right]^{3-}$ and six independent 4picolinium cations. The anions consist of four $\mathrm{Mo}_{3} \mathrm{O}_{13}$ units enwrapping the central $\mathrm{PO}_{4}$ tetrahedron. The $\mathrm{P}-\mathrm{O}$ bond lengths of the $\mathrm{PO}_{4}$ tetrahedron range from $1.531(3)$ to $1.539(3) \AA$ while the O-P-O angles are in the range from $109.21(18)$ to $109.72(18)^{\circ}$ which shows the $\mathrm{PO}_{4}$ tetrahedron to be almost regular. Each distorted $\mathrm{MoO}_{6}$ octahedron has one terminal oxygen atom $\left(\mathrm{O}_{\mathrm{t}}\right)$, four doubly bridging oxygen atoms $\left(\mathrm{O}_{\mathrm{b}}\right)$, and one triply bridging oxygen atom $\left(\mathrm{O}_{\mathrm{a}}\right)$,
Table 1. Crystal and refinement data for $\left(\mathrm{C}_{6} \mathrm{H}_{8} \mathrm{~N}\right)_{3}$ $\left[\mathrm{PMo}_{12} \mathrm{O}_{40}\right]$.

\begin{tabular}{ll}
\hline Formula & $\mathrm{C}_{18} \mathrm{H}_{24} \mathrm{~N}_{3} \mathrm{PMo}_{12} \mathrm{O}_{40}$ \\
$M_{\mathrm{r}}$ & 2104.65 \\
Crystal size, $\mathrm{mm}^{3}$ & $0.49 \times 0.21 \times 0.16$ \\
Crystal system & monoclinic \\
Space group & $P 2_{1} / c$ \\
$a, \AA$ & $19.7004(3)$ \\
$b, \AA$ & $14.0785(2)$ \\
$c, \AA$ & $33.0209(5)$ \\
$\beta$, deg & $91.3590(10)$ \\
$V, \AA^{3}$ & $9155.8(2)$ \\
$Z$ & 8 \\
$D_{\text {calcd }}, \mathrm{g} \mathrm{cm}^{-3}$ & 3.10 \\
$\mu\left(\mathrm{Mo} K_{\alpha}\right), \mathrm{cm}^{-1}$ & 3.1 \\
$F(000), \mathrm{e}$ & 7936 \\
$h k l$ range & $\pm 25, \pm 18, \pm 43$ \\
$T_{\min } / T_{\max }$ & $0.2931 / 0.6187$ \\
$\operatorname{Refl.~measured~/~unique~/~} R_{\text {int }}$ & $70690 / 21776 / 0.0323$ \\
Param. refined & 1333 \\
$R 1(F) / w R 2\left(F^{2}\right)^{\mathrm{a}, \mathrm{b}}($ all refl. $)$ & $0.0536 / 0.0845$ \\
$\mathrm{GoF}\left(F^{2}\right)^{\mathrm{c}}$ & 1.016 \\
$\Delta \rho_{\text {fin }}(\max / \mathrm{min}), \mathrm{e} \AA^{-3}$ & $1.32 /-1.10$ \\
\hline
\end{tabular}

${ }^{\mathrm{a}} R 1=\Sigma|| F_{\mathrm{o}}|-| F_{\mathrm{c}} \| / \Sigma\left|F_{\mathrm{o}}\right| ;{ }^{\mathrm{b}} w R 2=\left[\Sigma w\left(F_{\mathrm{o}}{ }^{2}-{F_{\mathrm{c}}}^{2}\right)^{2} / \Sigma w\left(F_{\mathrm{o}}{ }^{2}\right)^{2}\right]^{1 / 2}$, $w=\left[\sigma^{2}\left(F_{\mathrm{o}}{ }^{2}\right)+(\mathrm{A} P)^{2}+\mathrm{B} P\right]^{-1}$, where $P=\left(\operatorname{Max}\left(F_{\mathrm{o}}{ }^{2}, 0\right)+2 F_{\mathrm{c}}{ }^{2}\right) / 3$; ${ }^{\mathrm{c}} \mathrm{GoF}=\left[\Sigma w\left(F_{\mathrm{o}}{ }^{2}-F_{\mathrm{c}}{ }^{2}\right)^{2} /\left(n_{\mathrm{obs}}-n_{\text {param }}\right)\right]^{1 / 2}$.

with $\mathrm{O}-\mathrm{Mo}-\mathrm{O}$ bond angles ranging from 71.87(12) to $172.09(16)^{\circ}$. The $\mathrm{Mo}-\mathrm{O}_{\mathrm{t}}, \mathrm{Mo}-\mathrm{O}_{\mathrm{b}}, \mathrm{Mo}-\mathrm{O}_{\mathrm{a}}$ bond lengths are in the ranges $1.663(4)$ to $1.683(4) \AA$, 1.835 (3) to 2.000(4) $\AA$, and 2.417(3) to 2.453(3) $\AA$, respectively. The $\mathrm{C}-\mathrm{C}$ bond lengths of the 4-picolinium 
Table 2. Hydrogen-bonding geometry ( $\AA$, deg) for $\left(\mathrm{C}_{6} \mathrm{H}_{8} \mathrm{~N}\right)_{3}\left[\mathrm{PMo}_{12} \mathrm{O}_{40}\right]^{\mathrm{a}}$.

\begin{tabular}{lclc}
\hline Donor-H $\cdots$ Acceptor & $\mathrm{H} \cdots \mathrm{A}$ & $\mathrm{D} \cdots \mathrm{A}$ & $\mathrm{D}-\mathrm{H} \cdots \mathrm{A}$ \\
\hline $\mathrm{N}(1)-\mathrm{H}(1 \mathrm{D}) \cdots \mathrm{O}(53)$ & 1.97 & $2.809(6)$ & 164 \\
$\mathrm{~N}(2)-\mathrm{H}(2 \mathrm{~A}) \cdots \mathrm{O}(3)$ & 2.45 & $3.004(7)$ & 123 \\
$\mathrm{~N}(2)-\mathrm{H}(2 \mathrm{~A}) \cdots \mathrm{O}(23)$ & 2.49 & $3.111(7)$ & $130^{\prime}$ \\
$\mathrm{N}(3)-\mathrm{H}(3 \mathrm{~A}) \cdots \mathrm{O}(45)$ & 2.30 & $2.954(7)$ & 133 \\
$\mathrm{~N}(3)-\mathrm{H}(3 \mathrm{~A}) \cdots \mathrm{O}(4)[2655]$ & 2.49 & $3.164(7)$ & $136^{\prime}$ \\
$\mathrm{N}(4)-\mathrm{H}(4 \mathrm{~B}) \cdots \mathrm{O}(22)[4555]$ & 2.55 & $2.918(8)$ & 107 \\
$\mathrm{~N}(5)-\mathrm{H}(5 \mathrm{~B}) \cdots \mathrm{O}(28)[1565]$ & 2.36 & $3.210(6)$ & 168 \\
$\mathrm{~N}(6)-\mathrm{H}(6 \mathrm{~B}) \cdots \mathrm{O}(54)[1545]$ & 2.21 & $3.063(6)$ & 172 \\
$\mathrm{C}(1)-\mathrm{H}(1 \mathrm{C}) \cdots \mathrm{O}(56)[2555]$ & 2.37 & $3.090(10)$ & 132 \\
$\mathrm{C}(1)-\mathrm{H}(1 \mathrm{C}) \cdots \mathrm{O}(56)[4565]$ & 2.58 & $3.201(8)$ & $123^{\prime}$ \\
$\mathrm{C}(4)-\mathrm{H}(4 \mathrm{~A}) \cdots \mathrm{O}(46)$ & 2.40 & $3.218(8)$ & 147 \\
$\mathrm{C}(8)-\mathrm{H}(8 \mathrm{~A}) \cdots \mathrm{O}(49)[2545]$ & 2.53 & $3.271(7)$ & 137 \\
$\mathrm{C}(10)-\mathrm{H}(10 \mathrm{~A}) \cdots \mathrm{O}(34)[2645]$ & 2.43 & $3.237(8)$ & 145 \\
$\mathrm{C}(12)-\mathrm{H}(12 \mathrm{C}) \cdots \mathrm{O}(1)$ & 2.52 & $3.278(8)$ & 136 \\
$\mathrm{C}(17)-\mathrm{H}(17 \mathrm{~A}) \cdots \mathrm{O}(7)[1565]$ & 2.59 & $3.073(7)$ & 112 \\
$\mathrm{C}(19)-\mathrm{H}(19 \mathrm{~A}) \cdots \mathrm{O}(62)[3575]$ & 2.46 & $3.275(7)$ & 147 \\
$\mathrm{C}(32)-\mathrm{H}(32 \mathrm{~A}) \cdots \mathrm{O}(46)$ & 2.57 & $3.317(8)$ & 138 \\
$\mathrm{C}(33)-\mathrm{H}(33 \mathrm{~A}) \cdots \mathrm{O}(1)$ & 2.58 & $3.280(8)$ & 133 \\
$\mathrm{C}(33)-\mathrm{H}(33 \mathrm{~A}) \cdots \mathrm{O}(27)$ & 2.52 & $3.190(8)$ & $129^{\prime}$ \\
$\mathrm{C}(35)-\mathrm{H}(35 \mathrm{~A}) \cdots \mathrm{O}(75)[2545]$ & 2.44 & $3.235(7)$ & 144 \\
$\mathrm{C}(36)-\mathrm{H}(36 \mathrm{~B}) \cdots \mathrm{O}(46)$ & 2.58 & $3.210(8)$ & 123 \\
$\mathrm{C}(36)-\mathrm{H}(36 \mathrm{C}) \cdots \mathrm{O}(8)[2655]$ & 2.57 & $3.320(7)$ & 135 \\
\hline a Symmetry operations: [1545] $=x,-1+y, z ;[4565]=x, 3 / 2-y$, \\
$1 / 2+z ;[3575]=-x, 2-y,-z ;[4555]=x, 1 / 2-y, 1 / 2+z ;[2655]=$ \\
$1-x, 1 / 2+y, 1 / 2-z ;[1565]=x, 1+y, z ;[2555]=-x, 1 / 2+y$, \\
$1 / 2-z ;[2645]=1-x,-1 / 2+y, 1 / 2-z ;[2545]=-x,-1 / 2+y$, \\
$1 / 2-z$.
\end{tabular}

Table 3. Selected bond lengths $(\AA)$ and angles (deg) for $\left(\mathrm{C}_{6} \mathrm{H}_{8} \mathrm{~N}\right)_{3}\left[\mathrm{PMo}_{12} \mathrm{O}_{40}\right]$ with estimated standard deviations in parentheses.

\begin{tabular}{lrlr}
\hline $\mathrm{Mo}(1)-\mathrm{O}(60)$ & $1.677(3)$ & $\mathrm{Mo}(1)-\mathrm{O}(65)$ & $1.836(3)$ \\
$\mathrm{Mo}(1)-\mathrm{O}(70)$ & $1.861(4)$ & $\mathrm{Mo}(1)-\mathrm{O}(55)$ & $1.965(4)$ \\
$\mathrm{Mo}(1)-\mathrm{O}(52)$ & $2.030(3)$ & $\mathrm{Mo}(1)-\mathrm{O}(51)$ & $2.431(3)$ \\
$\mathrm{O}(66)-\mathrm{P}(2)$ & $1.531(3)$ & $\mathrm{O}(74)-\mathrm{P}(2)$ & $1.539(3)$ \\
$\mathrm{O}(51)-\mathrm{P}(2)$ & $1.534(3)$ & $\mathrm{O}(79)-\mathrm{P}(2)$ & $1.535(3)$ \\
$\mathrm{O}(60)-\mathrm{Mo}(1)-\mathrm{O}(65)$ & $104.94(17)$ & $\mathrm{O}(65)-\mathrm{Mo}(1)-\mathrm{O}(51)$ & $86.91(13)$ \\
$\mathrm{O}(60)-\mathrm{Mo}(1)-\mathrm{O}(70)$ & $102.65(17)$ & $\mathrm{O}(65)-\mathrm{Mo}(1)-\mathrm{O}(55)$ & $86.36(15)$ \\
$\mathrm{O}(60)-\mathrm{Mo}(1)-\mathrm{O}(55)$ & $101.25(17)$ & $\mathrm{O}(65)-\mathrm{Mo}(1)-\mathrm{O}(70)$ & $96.72(16)$ \\
$\mathrm{O}(60)-\mathrm{Mo}(1)-\mathrm{O}(52)$ & $96.61(16)$ & $\mathrm{O}(65)-\mathrm{Mo}(1)-\mathrm{O}(52)$ & $157.18(14)$ \\
$\mathrm{O}(60)-\mathrm{Mo}(1)-\mathrm{O}(51)$ & $168.04(15)$ & $\mathrm{O}(52)-\mathrm{Mo}(1)-\mathrm{O}(51)$ & $71.87(12)$ \\
$\mathrm{O}(70)-\mathrm{Mo}(1)-\mathrm{O}(51)$ & $73.84(12)$ & $\mathrm{O}(55)-\mathrm{Mo}(1)-\mathrm{O}(51)$ & $80.78(12)$ \\
$\mathrm{O}(70)-\mathrm{Mo}(1)-\mathrm{O}(52)$ & $85.60(15)$ & $\mathrm{O}(55)-\mathrm{Mo}(1)-\mathrm{O}(52)$ & $82.12(15)$ \\
$\mathrm{O}(70)-\mathrm{Mo}(1)-\mathrm{O}(55)$ & $154.20(14)$ & & \\
$\mathrm{O}(66)-\mathrm{P}(2)-\mathrm{O}(51)$ & $109.52(18)$ & $\mathrm{O}(66)-\mathrm{P}(2)-\mathrm{O}(79)$ & $109.48(18)$ \\
$\mathrm{O}(66)-\mathrm{P}(2)-\mathrm{O}(74)$ & $109.47(19)$ & $\mathrm{O}(79)-\mathrm{P}(2)-\mathrm{O}(74)$ & $109.43(18)$ \\
$\mathrm{O}(51)-\mathrm{P}(2)-\mathrm{O}(79)$ & $109.72(18)$ & $\mathrm{O}(51)-\mathrm{P}(2)-\mathrm{O}(74)$ & $109.21(18)$ \\
$\mathrm{Mo}(1)-\mathrm{O}(51)-\mathrm{Mo}(15)$ & $89.15(11)$ & $\mathrm{P}(2)-\mathrm{O}(51)-\mathrm{Mo}(1)$ & $125.47(17)$ \\
$\mathrm{Mo}(1)-\mathrm{O}(51)-\mathrm{Mo}(4)$ & $88.96(10)$ & $\mathrm{P}(2)-\mathrm{O}(51)-\mathrm{Mo}(15)$ & $126.31(17)$ \\
$\mathrm{Mo}(15)-\mathrm{O}(51)-\mathrm{Mo}(4)$ & $90.05(10)$ & $\mathrm{P}(2)-\mathrm{O}(51)-\mathrm{Mo}(4)$ & $125.29(19)$ \\
$\mathrm{Mo}(12)-\mathrm{O}(55)-\mathrm{Mo}(1)$ & $151.2(2)$ & $\mathrm{Mo}(1)-\mathrm{O}(65)-\mathrm{Mo}(8)$ & $151.0(2)$ \\
$\mathrm{Mo}(8)-\mathrm{O}(59)-\mathrm{Mo}(12)$ & $152.8(2)$ & & \\
\hline
\end{tabular}

cations range from $1.343(12)$ to $1.492(8) \AA$, and the $\mathrm{C}-\mathrm{N}$ bond lengths are in the range from $1.320(8)$ to $1.340(10) \AA$, thus exhibiting normal $\mathrm{C}-\mathrm{C}$ and $\mathrm{C}-\mathrm{N}$ distances (Fig. 1).

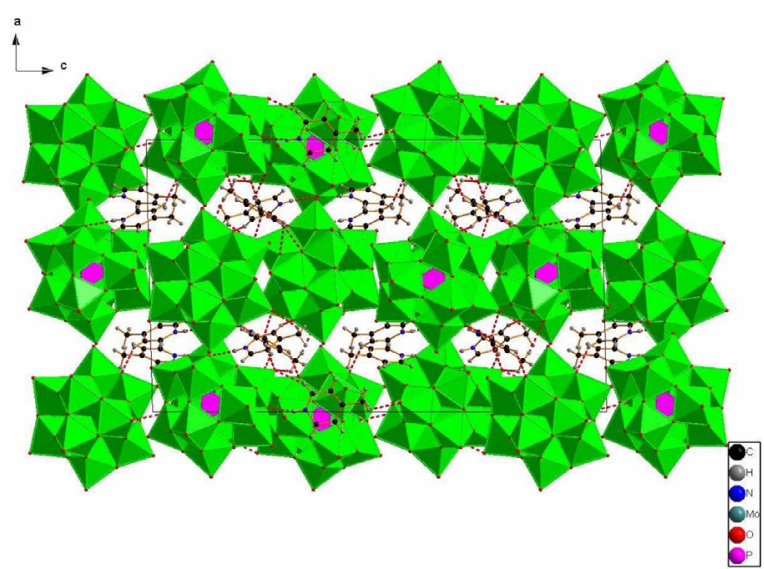

Fig. 2 (color online). Packing of the cationic and anionic units in the crystal structure of $\left(\mathrm{C}_{6} \mathrm{H}_{8} \mathrm{~N}\right)_{3}\left[\mathrm{PMo}_{12} \mathrm{O}_{40}\right]$.

Several intermolecular $\mathrm{N}-\mathrm{H} \cdots \mathrm{O}$ hydrogen bonds $(d(\mathrm{~N}-\mathrm{O})=2.809-3.320 \AA)$ are found in the title compound (Table 2), stabilizing the supramolecular structure (Fig. 2) [13]. Selected bond lengths ( $\AA$ ) and angles (deg) are listed in Table 3.

\section{IR spectroscopy}

The IR spectrum of $\left(\mathrm{C}_{6} \mathrm{H}_{8} \mathrm{~N}\right)_{3}\left[\mathrm{PMo}_{12} \mathrm{O}_{40}\right]$ shows the characteristic absorption peaks of the Keggin anions at $v=1061.15\left(\mathrm{P}-\mathrm{O}_{\mathrm{a}}\right), 958.14\left(\mathrm{Mo}-\mathrm{O}_{\mathrm{t}}\right), 877.77$ $\left(\mathrm{Mo}-\mathrm{O}_{\mathrm{a}}\right)$, and $797.50 \mathrm{~cm}^{-1}\left(\mathrm{Mo}-\mathrm{O}_{\mathrm{b}}\right)$. The bands of the 4-picolinium cations appear at 2972-2901 and 1612$1169 \mathrm{~cm}^{-1}[10]$.

Comparing the IR spectrum of the title compound with that of $\mathrm{H}_{3} \mathrm{PMo}_{12} \mathrm{O}_{40} \cdot n \mathrm{H}_{2} \mathrm{O}(v=1064.25$ $\left(\mathrm{P}-\mathrm{O}_{\mathrm{a}}\right), 962.66\left(\mathrm{Mo}-\mathrm{O}_{\mathrm{t}}\right), 869.74\left(\mathrm{Mo}-\mathrm{O}_{\mathrm{a}}\right)$, and 781.84 $\left(\mathrm{Mo}-\mathrm{O}_{\mathrm{b}}\right) \mathrm{cm}^{-1}$ ) [12], the vibrational bands of the $\mathrm{P}-\mathrm{O}_{\mathrm{a}}$ and the $\mathrm{Mo}-\mathrm{O}_{\mathrm{t}}$ bond have a small red shift, while the vibrational bands of the $\mathrm{Mo}-\mathrm{O}_{\mathrm{a}}$ and $\mathrm{Mo}-\mathrm{O}_{\mathrm{b}}$ bond are blue-shifted. This demonstrates that the $\mathrm{P}-\mathrm{O}_{\mathrm{a}}$ and the $\mathrm{Mo}-\mathrm{O}_{\mathrm{t}}$ bonds become weaker, and the $\mathrm{Mo}-\mathrm{O}_{\mathrm{a}}$ and $\mathrm{Mo}-\mathrm{O}_{\mathrm{b}}$ bonds become stronger in this compound. The IR spectrum indicates that there are interactions between the $\left[\mathrm{PMo}_{12} \mathrm{O}_{40}\right]^{3-}$ anions and the $\left[\mathrm{C}_{6} \mathrm{H}_{8} \mathrm{~N}\right]^{+}$ cations in the solid state.

\section{TG-DTA analysis}

The TG-DTA analysis of the title compound shows four exothermic peaks, at 309.1, 350.2 (a shoulder peak), 365.9, and $426.7^{\circ} \mathrm{C}$, accompanied by considerable weight loss. From $575{ }^{\circ} \mathrm{C}$ on the TG curve presents a platform. Below $400{ }^{\circ} \mathrm{C}$, the TG curve exhibits a weight loss of $13.0 \%$ (calcd. 13.4\%), 
corresponding to the release of three 4-picoline molecules. The decomposition of the heteropolyacid $\mathrm{H}_{3} \mathrm{PMo}_{12} \mathrm{O}_{40}$ is found at $426.7^{\circ} \mathrm{C}$. The final residue, whose weight is $80.3 \%$ (calcd. $82.1 \%$ ), is $\mathrm{MoO}_{3}$.

\section{Catalytic reaction for acetone elimination}

Blank experiments showed that acetone in a simulacrum of polluted air was hardly eliminated oxidatively without a catalyst. The test results of the effluent gases showed that there was no new peak in the GC diagram which indicated that no other organic compounds were formed. In lime-saturated water a precipitate occured while the color of a $0.2 \% \mathrm{PdCl}_{2}$ solution did not change, indicating that there was $\mathrm{CO}_{2}$ but no $\mathrm{CO}$. Products of the elimination of acetone thus were $\mathrm{CO}_{2}$ and $\mathrm{H}_{2} \mathrm{O}$, as expected.

The title compound shows a high catalytic activity for the oxidative elimination of acetone as tested in a continuous-flow fixed-bed micro-reactor. The effect of reaction temperature on the elimination rate of acetone is shown in Fig. 3. The best catalytic reaction temperature is $70{ }^{\circ} \mathrm{C}$. When the flow rate is $3.3 \mathrm{~mL} \mathrm{~min}^{-1}$ and the initial concentration is $5.2 \mathrm{~g} \mathrm{~m}^{-3}$ in the air, the overall elimination of acetone is $93 \%$ at $70{ }^{\circ} \mathrm{C}$. The acetone residue meets the discharge standard. When the reaction temperature is higher than $80{ }^{\circ} \mathrm{C}$, the elimination rate of acetone is reduced because high temperatures promote the desorption of acetone. The title compound is stable, and it retains a good catalytic activity with continuous reaction over $80 \mathrm{~h}$.

\section{Conclusions}

The title compound $\left(\mathrm{C}_{6} \mathrm{H}_{8} \mathrm{~N}\right)_{3}\left[\mathrm{PMo}_{12} \mathrm{O}_{40}\right]$ consisting of $\left[\mathrm{PMo}_{12} \mathrm{O}_{40}\right]^{3-}$ Keggin heteropolyoxoanions and $\left[\mathrm{C}_{6} \mathrm{H}_{8} \mathrm{~N}\right]^{+}$(4-picolinium) cations has been synthesized. A supramolecular structure is formed via intermolecular hydrogen-bonding between the different structural units. The compound shows high catalytic activity for the oxidative elimination of acetone from air. With initial acetone concentrations of $5.2 \mathrm{~g} \mathrm{~m}^{-3}$ and flow rates of $3.3 \mathrm{~mL} \mathrm{~min}^{-1}$, the elimination rate of acetone is $93.2 \%$ at $70{ }^{\circ} \mathrm{C}$. The catalytic activity of the compound is stable for at least $80 \mathrm{~h}$ allowing continuous operation.

\section{Experimental Section}

All reagents were purchased and used without further purification. The elemental analysis was performed using a

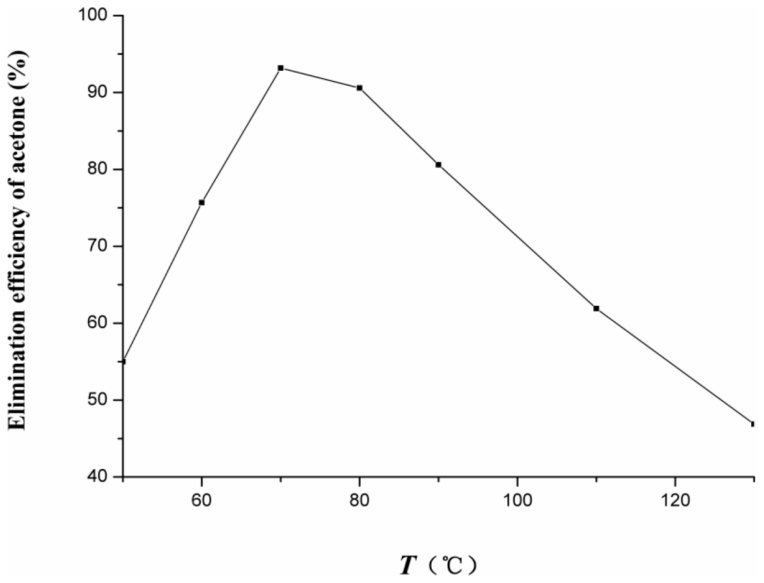

Fig. 3. Effect of the reaction temperature on the elimination rate of acetone.

Perkin-Elmer $2400 \mathrm{CHNS/O}$ analyzer. The contents of Mo and $\mathrm{P}$ were determined by a Shimadzu ICPS-7510 instrument. The infrared spectrum was recorded on a PerkinElmer FTIR-2000 spectrophotometer on $\mathrm{KBr}$ pellets (4000 $400 \mathrm{~cm}^{-1}$ ). The TG-DTA analysis was carried out at a WCT-1D differential thermal balance (Beijing Optical Instrument Factory, China) in air atmosphere with a heating rate of $10{ }^{\circ} \mathrm{C} \mathrm{min}-1$.

\section{Hydrothermal synthesis}

A mixture of $\mathrm{Na}_{3} \mathrm{PO}_{4} \cdot 12 \mathrm{H}_{2} \mathrm{O}(0.1520 \mathrm{~g}, 0.20 \mathrm{mmol})$, and $\mathrm{Na}_{2} \mathrm{MoO}_{4} \cdot 2 \mathrm{H}_{2} \mathrm{O}(0.5800 \mathrm{~g}, 2.40 \mathrm{mmol})$ in $\mathrm{H}_{2} \mathrm{O}(15.00 \mathrm{~mL})$ was acidified $(\mathrm{pH}=1.80)$ by dilute sulfuric acid. After stirring the mixture for $3 \mathrm{~h}$ at $70{ }^{\circ} \mathrm{C}$, 4-picoline $(0.03 \mathrm{~mL}$, $0.30 \mathrm{mmol}$ ) was added. The new mixture was sealed in a $25 \mathrm{~mL}$ Teflon-lined bomb and heated at $453 \mathrm{~K}$ for $120 \mathrm{~h}$, then slowly cooled to r.t. Black stick-like crystals were collected by filtration, washed with distilled water and dried in air to give a yield of $59.9 \%$ based on the initial 4-picoline input. Analytical data for $\mathrm{C}_{18} \mathrm{H}_{24} \mathrm{~N}_{3} \mathrm{PMo}_{12} \mathrm{O}_{40}$ (2104.65): calcd. C 10.27, H 1.15, N 2.00, Mo 54.70, P 1.47; found C 10.35, H 1.10, N 2.06, Mo 55.20, P 1.51.

\section{$X$-Ray structure determination}

The reflection intensities of a black crystal of the title compound were collected at $273 \mathrm{~K}$ using a Bruker SMART Apex II CCD area detector single-crystal diffractometer with graphite-monochromatized $\operatorname{Mo} K_{\alpha}$ radiation $(\lambda=0.71073 \AA)$, by the $\omega$ scan method. The absorption corrections were based on multiple and symmetry-equivalent reflections in the data set using the program SADABS [14]. The structure was solved by Direct Methods and refined by full-matrix leastsquares on $F^{2}$ using the SHELXTL [15] program package. All hydrogen atoms were refined isotropically as a riding 


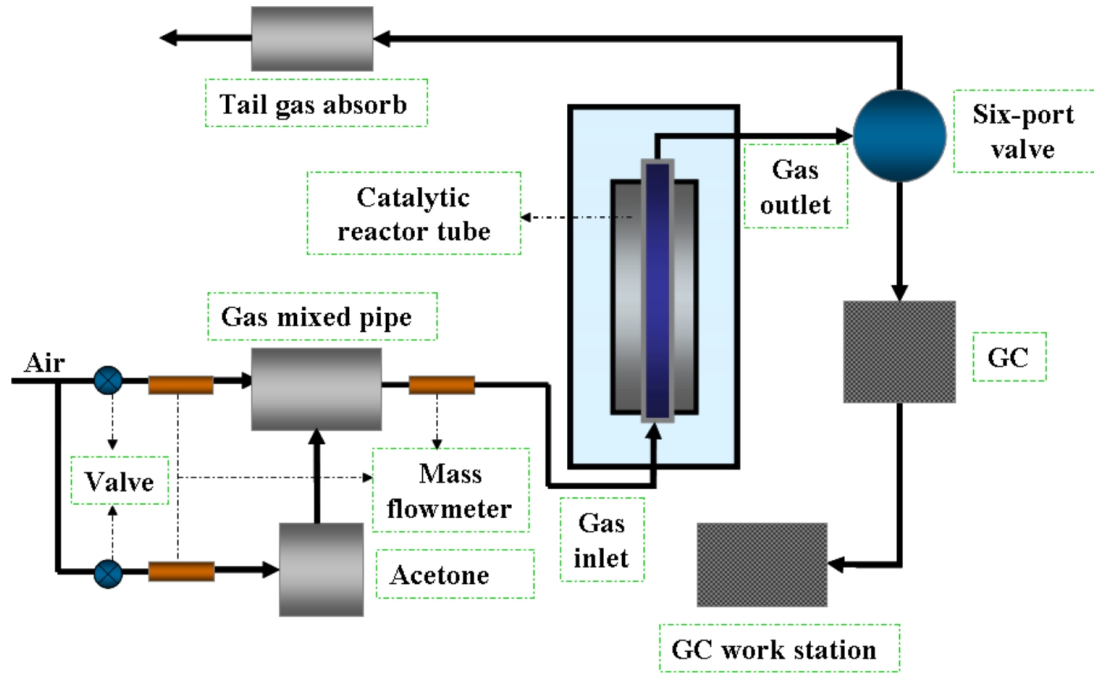

Fig. 4 (color online). Continuousflow reaction system. model using the default SHELXTL parameters. Detailed information about the crystal data and structure determination are summarized in Table 1.

CCDC 803693 contains the supplementary crystallographic data for this paper. These data can be obtained free of charge from The Cambridge Crystallographic Data Centre via www.ccdc.cam.ac.uk/data_request/cif.

\section{Catalytic reaction for acetone elimination}

The catalytic elimination of acetone was used as a model reaction to evaluate the catalytic performance of the title compound. Catalytic reactions were carried out in a continuous-flow fixed-bed micro-reactor (Fig. 4). $0.20 \mathrm{~g}$ of $\left(\mathrm{C}_{6} \mathrm{H}_{8} \mathrm{~N}\right)_{3}\left[\mathrm{PMo}_{12} \mathrm{O}_{40}\right]$ was loaded in the reaction tube $(\varnothing=$ $8 \mathrm{~mm} ; L=200 \mathrm{~mm}$ ) as catalyst. The simulacrum of polluted air was prepared by bubbling clean air into a container filled with acetone and diluting the gas with clean dry air. The initial acetone concentration of the reaction gas was controlled by changing the proportion of the bubbling gas and the diluent gas. The reactant gas was fed to the reactor at a flow rate of $3.3 \mathrm{~mL} \mathrm{~min}^{-1}$ and a concentration of $5.2 \mathrm{~g} \mathrm{~m}^{-3}$. The elimination rate of acetone was determined at different reaction temperatures.

The concentration of the organic compounds of the effluent gases after the reaction was analyzed on-line by a gas chromatograph GC102-N, equipped with a column packed with Porapak-Q and a flame ionization detector (FID). The inorganic products of the effluent gases were monitored by a 0.2 (wt.-\%) $\mathrm{PdCl}_{2}$ solution and a saturated limewater solution. Blank experiments were carried out without the catalyst.

\section{Acknowledgement}

The project was supported by the Human Provincial Science and Technology plan projects of China and the Key Laboratory of Theoretical Chemistry and Molecular Simulation of Ministry of Education, Hunan University of Science and Technology.
[1] Q. Chen, C. L. Hill, Inorg. Chem. 1996, 35, $2403-$ 2405.

[2] F.-Q. Zhang, X.-M. Zhang, H.-S. Wu, H.-J. Jiao, J. Phys. Chem. A 2007, 111, 159-166.

[3] P. Song, L.-K. Yan, W. Guan, J.-D. Feng, C.-G. Liu, Z.-M. Su, Chin. Sci. Bull. 2009, 54, $203-211$.

[4] J. Martin-Frère, Y. Jeannin, F. Robert, J. Vaissermann, Inorg. Chem. 1991, 30, 3635-3639.

[5] R.-G. Cao, S.-X. Liu, L.-H. Xie, Y.-B. Pan, J.-F. Cao, Y.-H. Ren, L. Xu, Inorg. Chem. 2007, 46, 3541 - 3547.

[6] J.-P. Wang, W. Wang, J.-Y. Niu, Chin. J. Struct. Chem. 2007, 26, $194-198$.
[7] W.-S. You, E.-B. Wang, Y. Xu, Y.-G. Li, L. Xu, C.-W. $\mathrm{Hu}$, Inorg. Chem. 2001, 40, $5468-5471$.

[8] B. Li, S.-T. Zheng, G.-Y. Yang, Chin. J. Struct. Chem. 2009, 28, 531-536.

[9] Y. Lu, Y. Xu, E.-B. Wang, J. Lu, C.-W. Hu, L. Xu, Crystal Growth \& Design 2005, 5, 257-260.

[10] Y.-H. Zhou, H. Zhang, L. Guan, S.-X. Cui, Y.-Y. Pang, Chin. J. Struct. Chem. 2009, 28, $72-76$.

[11] Y. Xia, P.-F. Wu, Y.-G. Wei, Y. Wang, H.-Y. Guo, Crystal Growth \& Design 2006, 6, 253-257.

[12] S. Lin, Y.-Z. Yea, X.-F. Zhang, C.-L. Liu, Trans. Met. Chem. 2006, 31, 760-764. 
[13] B. Hu, J.-Z. Chen, H.-Chen , Z.-F. Li, Z. Kristallogr. NCS 2008, 223, 432-434.

[14] G. M. Sheldrick, SADABS, Program for Empirical Absorption Correction of Area Detector Data, University of Göttingen, Göttingen (Germany) 1996.
[15] G. M. Sheldrick, SHELXTL, Software Reference Manual, Bruker Analytical X-ray Instruments Inc., Madison, Wisconsin (USA) 1997. See also: G. M. Sheldrick, Acta Crystallogr. 1990, A46, 467-473; ibid. 2008, A64, $112-122$. 